\title{
PHYSICAL AND CHEMICAL ATTRIBUTES OF ARCHAEOLOGICAL SOILS DEVELOPED FROM SHELL MIDDENS IN THE REGIÃO DOS LAGOS, RIO DE JANEIRO, BRAZIL ${ }^{(1)}$
}

\author{
Guilherme Resende Corrêa ${ }^{(2)}$, Carlos Ernesto G.R. Schaefer ${ }^{(3)}$, \\ Vander de Freitas Melo ${ }^{(4)}$, Kleberson Worslley de Souza ${ }^{(5)}$, \\ João Carlos Ker ${ }^{(3)}$, Igor Morais Mariano Rodrigues ${ }^{(6)}$ \& \\ Eduardo Osório Senra ${ }^{(7)}$
}

\begin{abstract}
SUMMARY
In prehistoric times, innumerous shell middens, called "sambaquis", consisting mainly of remains of marine organisms, were built along the Brazilian coast. Although the scientific community took interest in these anthropic formations, especially since the nineteenth century, their pedological context is still poorly understood. The purpose of this study was to characterize and identify the physical and chemical changes induced by soil-forming processes, as well as to compare the morphology of shell midden soils with other, already described, anthropogenic soils of Brazil. Four soil profiles developed from shell middens in the Região dos Lagos - RJ were morphologically described and the physical and chemical properties determined. The chemical analysis showed that $\mathrm{Ca}, \mathrm{Mn}, \mathrm{Mg}$, and particularly $\mathrm{P}$ and $\mathrm{Zn}$ are indicators of anthropic horizons of midden soils, as in the Amazon Dark Earths (Terras Pretas de Índio). After the deposition of P-rich material, $P$ reaction and leaching can mask or disturb the evidence of in situ man-
\end{abstract}

(1) Research carried out at the Post-Graduate program in Soils and Plant Nutrition of the Federal University of Viçosa - UFV. Received for publication in December 11, 2009 and approved in May 2, 2011.

(2) DSc student at the Post-Graduate program in Soils and Plant Nutrition of the Federal University of Viçosa - UFV. Av. P. H. Rolfs sn, CEP 36570-000 Viçosa (MG). CNPq scholar. E-mail: guilhermeudi@yahoo.combr

(3) Associate Professor, Soil Science Department, UFV. E-mail: carlos.schaefer@ufv.br; jcker@ufv.br

(4) Associate Professor, Soil Science and Agriculture Engineering Department, Federal University of Paraná - UFPR. Rua dos Funcionários 1540, CEP 80035-050 Curitiba (PR). E-mail: vanderfm@ufpr.br

(5) Assistant Professor, Federal University of Amazonas, Manaus. E-mail: klebersonws@gmail.com

(6) MSc student, Arquaeology Post-Graduate program in Anthropology, Federal University of Minas Gerais - UFMG. Av. Presidente Antônio Carlos 6627, Campus da UFMG, Pampulha, CEP 31270-901 Belo Horizonte (MG). E-mail: igor_mmrodrigues@hotmail.com

(7) MSc student at the Post-Graduate program in Soils and Plant Nutrition of the Federal University of Viçosa - UFV. CNPq scholar; senra.eduardo@gmail.com 
made strata, but mineralogical and chemical studies of phosphate forms can elucidate the apparent complexity. Lower phosphate-rich strata without direct anthropic inputs indicate $P$ leaching and precipitation in secondary forms. The total and bioavailable contents of $\mathrm{Ca}, \mathrm{Mg}, \mathrm{Zn}, \mathrm{Mn}, \mathrm{Cu}, \mathrm{P}$, and organic $\mathrm{C}$ of midden soils were much higher than of regional soils without influence of ancient human settlements, demonstrating that the high fertility persisted for long periods, at some sites for more than $\mathbf{4 0 0 0}$ years. The physical analysis showed that windblown sand contributed significantly to increase the sand fraction in the analyzed soils (texture classes sand, sandy loam and sandy clay loam) and that the aeolian sand accumulation occurred simultaneously with the midden formation.

Index terms: sambaquis, pre-columbian settlements; anthropic contribution; anthropogenic soils, Indian Black-Earth.

\section{RESUMO: ATRIBUTOS FÍSICOS E QUÍMICOS DE SOLOSARQUEOLÓGICOS DESENVOLVIDOS DE SAMBAQUIS DA REGIÃO DOS LAGOS- $R J, B R A S I L$}

Ao longo do litoral brasileiro foram erigidos, na pré-história, centenas de depósitos, constituidos principalmente por restos de organismos marinhos, denominados sambaquis. Essas formações de origem antrópica despertaram a curiosidade da comunidade científica, especialmente a partir do século XIX; entretanto, permanecem pouco conhecidas no contexto pedológico. Este trabalho objetivou caracterizar e identificar resultados dos processos pedogenéticos, que produziram alterações físico-químicas e morfológicas, bem como comparar solos de sambaquis com outros solos antropogênicos do Brasil, já conhecidos. Quatro perfis de solos desenvolvidos de sambaquis na Região dos Lagos - RJ foram estudados. Os solos foram descritos morfologicamente, e amostras foram coletadas para execução de análises físicas e químicas. As análises químicas revelaram que os elementos $\mathrm{Ca}, \mathrm{Mn}, \mathrm{Mg}$ e, especialmente, $P$ e Zn são indicadores de horizontes antrópicos de solos de sambaquis, à semelhança das Terras Pretas de Índio da Amazônia. Após a deposição de materiais ricos em fósforo, reações e lixiviação podem alterar drasticamente as evidências de camadas feitas pelo homem in situ, porém estudos químicos e mineralógicos das formas de fósforo podem elucidar a complexidade aparente. Horizontes ricos em fósforo sem a deposição direta de materiais antrópicos indicam a lixiviação de Pe sua precipitação em formas secundárias. Os teores de $\mathrm{Ca}, \mathrm{Mg}, \mathrm{Zn}, \mathrm{Mn}, \mathrm{Cu}$, $P$ e C-orgânico dos solos de sambaquis são muito maiores em comparação aos dos solos regionais sem interferência de antigos assentamentos humanos, o que demonstra a permanência de elevada fertilidade por longo período - em alguns sítios, superior a 4 mil anos. Quanto às análises físicas, elas mostraram que o aporte eólico de areias foi significativo no incremento dessa fração na composição dos solos analisados - todos se mostraram entre as classes texturais areia, franco-arenosa e franco-argiloarenosa - e que o acúmulo de areias eólicas foi contemporâneo à formação dos sambaquis.

Termos de indexação: assentamentos pré-colombianos, solos antropogênicos, pedogênese, Terra Preta de Índio.

\section{INTRODUCTION}

One of the most unique and significant archaeological remains left by pre-Columbian peoples on Brazilian territory are the Sambaquis, or shell middens, commonly found in several coastal areas of the world (Goldberg \& Macphail, 2006). The oldest in Brazil were dated at about 8000 and the youngest around 2000 years before present (BP), (Prous, 1992). The coastal middens in the form of hillocks have a diversified physiognomy, e.g., semi-spherical, coneshaped, flat or elongated and have different sizes, with an average base diameter of some tens of meters (some with more than one hundred), and a height of 2-30 m (Lima, 2000). Occasionally, shell middens with over 30,000 $\mathrm{m}^{3}$ have been found (Kröne, 1914; Abreu, 1928; Leonardos, 1938; Duarte, 1968).

Coastal middens, or Sambaquis, consist basically of food remains (mollusk shells, bones of the terrestrial and marine fauna, as well as seeds), which contain numerous traces of human occupation, such as artifacts (made of stone, bone and shells), human burials, and hearth and housing structures (Barbosa \& Duda, 1996; Gaspar, 1999). 
Shell middens are found in Brazil ranging from the state of Rio Grande do Sul, to the mouth of the Amazon in Pará, but are absent, or drowned, along the east-west coastal sector between the states Maranhão and Rio Grande do Norte, where no lake formations were found (Penna, 1876; Prous, 1992, Lima, 2000). Middens are always associated to nutrient-rich environments, where food is abundant, along the coast or in continental fluvial-lacustrine systems near the large rivers estuaries. However, the shell mounds found in riverine environments are smaller than those along the coast. They occur along several Brazilian rivers, and are common in the regions of the lower Amazon and Ribeira de Iguape (Penna, 1876; Leonardos, 1938; Roosevelt, 1991).

Due to the way and time the shell mounds were constructed, they are not structured in a homogeneous body but contain significantly older remains in the lower layers than in the upper, peripheral material. This is reflected in the dating results (Prous, 1992), as well as the stage of pedogenesis of the material. According to Figuti (1999), the age difference between the base and the surface material of a midden can be more than 500 years, indicating that their formation took hundreds of years.

On the coast, the shell mounds were heaped up mostly in environments such as lagoon areas, estuaries, mangroves, and brackish ponds, all rich in fish, crustaceans, and mollusks. Such areas favored settlement, allowing long residence periods. However, marked environmental variations such as marine transgressions and regressions (Bigarella, 1954) forced the shell-midden peoples to dynamic adaptations to the environmental changes.

The shell midden peoples later became extinct or were incorporated into the Tupi-Guarani culture, which occupied most part of the Brazilian coast (Prous, 1992). Without their builders, the middens, merging with the landscape, became an edaphic contribution to the environment (Figure 1); their pedogenesis resulted in the establishment of contrasting vegetation (Kröne, 1914, Duarte 1968, Penna, 1876). The chemical conditions, such as alkaline $\mathrm{pH}$, and the continuous covering of the cultural remains, protecting them against weathering, resulted in a good preservation of the anthropic strata, turning these shell mounds into archaeological structures of great value (Prous, 1992).

From the early sixteenth century, the middens were intensively exploited for lime production, causing widespread, significant archaeological losses in many regions. In the northern region, which is the poorest in limestone, they were virtually wiped out (Penna, 1876).
Soil formation from middens can be interpreted, as defined Kämpf et al. (2003), as an essentially anthropogenic and anthropo-geomorphological activity, since the development is associated with long-term human settlements with additions of domestic waste, and based on earth constructions and landfill sites for housing and burial, respectively. The properties of these soils differ in the darker color and the presence of cultural remains (artifacts, burials, charcoal fragments, among others) from other soils, and are therefore characterized as Archeo-anthrosols ${ }^{(8)}$ or shellmidden soil (Kämpf et al., 2003; Goldberg \& Macphail, 2006).

The aim of this study was to characterize the main physical and chemical aspects of soils developed from shell middens in the Região dos Lagos - RJ, to clarify the processes of soil formation in coastal middens, leading to chemical and morphological changes in the deposited material, and its comparison with other, already described anthropogenic soils of Brazil.

\section{MATERIAL AND METHODS}

The Região dos Lagos is located in the south-central part of the Brazilian coastline, in the State of Rio de Janeiro (Figure 1). This is the driest region of the state, with an average annual rainfall of less than $800 \mathrm{~mm}$ and the predominant hypoxerophytic Caatinga vegetation (Brazil, 1983). Geologically, the landscape is composed of alkaline rocks, especially syenites, related to magmatic events of opening of the Atlantic Ocean, and metamorphic rocks of the crystalline bedrock, mostly gneiss (Brazil, 1983).

The studied region has the shape of a small peninsula, surrounded by sandy Quaternary sediments with a complex known as Morro do Atalaia in the center, consisting of metamorphic rocks, orthogneisses of the Cabo Frio Complex (Tenorio et al., 2005). In the Quaternary sandy plain lies the Lagoa de Araruama, with predominantly dunes and "restinga" (coastal sandy bars, covered with characteristic herbaceous/shrubby plants). In this part of the State of Rio de Janeiro, soils with rather peculiar morphological, mineralogical and chemical features are found, formed by pedogenic processes of alternating paleoclimates, at times humid, at times dry, represented by Luvisols, Argisols, Organosols, Planosols and Latosols (Camargo, 1979; Embrapa, 1979; Moniz et al., 1990; Ibraimo et al., 2004).

Four sites with midden soils (Kämpf et al., 2003; Goldberg \& Macphail, 2006) formed from shell mounds

\footnotetext{
(8) The term midden soil used in this study was not intended to support the concept of anthropogenic soils of the Brazilian System of Soil Classification, which to date contains no comparable definition of shell midden soils; the term refers to materials at sites of prehistoric human occupation, pedogenetically transformed, whose archaeological nature was substantially modified by pedogenesis; it represents a pedostratigraphic sequence in the sense used by Goldberg \& Macphail (2006).
} 


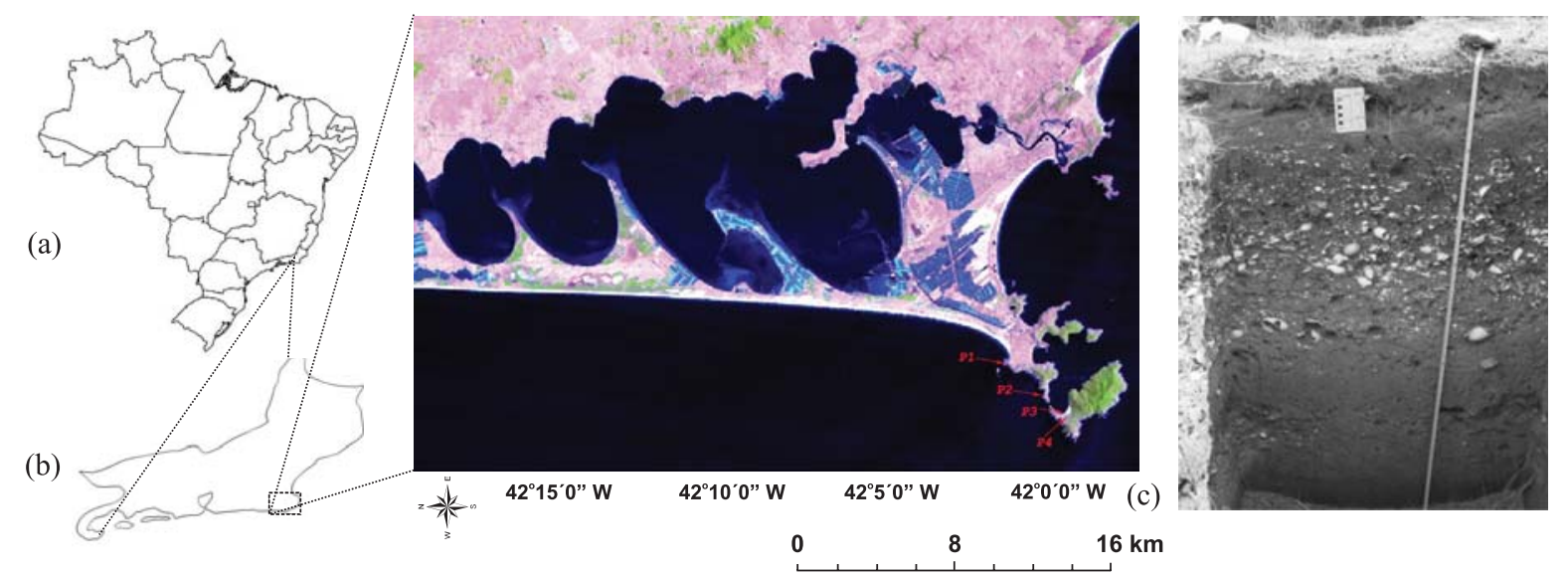

Figure 1. Location of the study area (a, b, c); image of one of the studied profiles (P4) (d).

were selected for the study in Arraial do Cabo (RJ), as follows: (a) Sítio do Condomínio do Atalaia (profile P1) on the hill of Atalaia, $50 \mathrm{~m}$ asl; (b) three occupation layers, dated at $4190 \pm 130$ and $4120 \pm 110 y r$ BP and the third layer at $1690 \pm 90 y r$ BP; (c) Sítio do Boqueirão (profile P2), $53 \mathrm{~m}$ asl, with two layers, apparently from two periods of occupation; the upper from $1623 \pm 32$ yr BP; (d) Sítio Ilha do Cabo Frio (profile P3), located in an area of little mobile dunes near the tide line, part of which is submerged, highest point at $20 \mathrm{~m}$ asl. Two occupation layers, in which two ages were determined at the basis of the site, at $2219 \pm 32$ and $1242 \pm 31$ yr BP; Sítio Usiminas (profile P4), $53 \mathrm{~m}$ asl on a large-scale dune, eight occupation layers, more than $160 \mathrm{~cm}$ deep; the fifth layer was dated at $1533 \pm$ 31 yr BP.

All ages and classifications of the above sites were obtained from the study of Tenorio et al. (2005). The profiles were described and the soil sampled as suggested by Santos et al. (2005). The soils were classified as proposed by Kämpf et al. (2003).

The samples collected in the horizons were airdried, loosened and sieved (2 $\mathrm{mm}$ mesh) to obtain airdried fine earth, which was analyzed as proposed by Embrapa (1997). The texture was analyzed using the pipette method, however, with slow agitation of $50 \mathrm{rpm}$ for $16 \mathrm{~h}$ (Ruiz, 2005a) and silt determination by a pipette method (Ruiz, 2005b); water-dispersible clay was determined by the method described for particle size analysis, with fast agitation (12,000 rpm for $15 \mathrm{~min}$ ) and without chemical dispersants. The $\mathrm{pH}$ was determined in water and in $\mathrm{KCl} 1 \mathrm{~mol} \mathrm{~L}^{-1}$ solution in a suspension soil/solution at a ratio of 1:2.5. Exchangeable cations were extracted by $\mathrm{KCl} 1 \mathrm{~mol} \mathrm{~L}^{-1}$ and quantified by atomic absorption spectrometry $\left(\mathrm{Ca}^{2+}\right.$ and $\left.\mathrm{Mg}^{2+}\right)$ and by titration with $\mathrm{NaOH}\left(\mathrm{Al}^{3+}\right)$. $\mathrm{Na}^{+}$was extracted with a solution of ammonium acetate $1.0 \mathrm{~mol} \mathrm{~L}^{-1}$ at $\mathrm{pH} 7.0$ and determined by flame photometry. The potential acidity $(\mathrm{H}+\mathrm{Al})$ was extracted with calcium acetate $0.5 \mathrm{~mol} \mathrm{~L}^{-1}$ at $\mathrm{pH} 7.0$ and quantified by titration with $\mathrm{NaOH}$. Available $\mathrm{P}$ and exchangeable $\mathrm{K}$ were extracted by Mehlich-1, $\mathrm{P}$ being measured by the ascorbic acid method as described by Kuo (1996), and $\mathrm{K}^{+}$determined by flame photometry. The available micronutrients $\mathrm{Cu}, \mathrm{Zn}$, Fe, and Mn were extracted by Mehlich-1 and determined by atomic absorption. The organic matter (OM) content was estimated after determining organic carbon by the Walkley Black method, without heating.

The fine earth was analyzed by sulphuric acid attack, with 1:1 $\mathrm{H}_{2} \mathrm{SO}_{4}$ (volume), heated to boiling under reflux with subsequent cooling, dilution and filtration. In the residue, $\mathrm{Si}$ was determined by alkaline extraction and $\mathrm{Fe}, \mathrm{P}, \mathrm{Mn}, \mathrm{Ti}, \mathrm{Cu}, \mathrm{Zn}$, and $\mathrm{Al}$ in the filtrate, by the method described by Embrapa (1997).

The total chemical analysis was carried out using fine earth solubilized in a mixture of concentrated $\mathrm{HF}$ $+\mathrm{HNO}_{3}+\mathrm{HCl}$, microwave-heated and pressed (USDA, 1996). Potassium and Na were determined by flame photometry, and $\mathrm{Fe}, \mathrm{Al}, \mathrm{Mg}, \mathrm{Mn}, \mathrm{Ca}, \mathrm{P}, \mathrm{Ti}$, BA, PB, Cd, Cr, Mo, Cu, V, Zn, and Sr by simultaneous readings of inductively coupled plasma-atomic emission spectrometry. (ICP-AES).

\section{RESULTS AND DISCUSSION}

\section{Physical analysis}

The sand fraction was significant in all soils (Table 1). This characteristic is due to the contribution of aeolian sand deposits, consisting mostly of quartz, featuring a dune landscape in areas with greater deposition. The abundance of 2-0.05 mm fragments from the prehistoric human activities also contributed to higher values of the sand fraction. No contribution of clayey material to the sites was observed in any of the soil profiles, in contrast to results of Tenorio et al. (2005), who found a clay underground at the Sítio Condomínio do Atalaia. This result may be due to a 
discontinuity of the clayey material, therefore absent in P1.

The textural variations along the profiles $\mathrm{P} 1$ and P2 (Table 1) are minor but subtle differences in color and amount of rubble and other materials (frequently anthropogenic), distinguished the pedogenic horizons. However, the sites differ in the landscape position; at the Sítio Condomínio do Atalaia, in a more flat and open part, the deposition of coarser sand particles was intensified, due to the greater wind power bringing more coarse material than to the area of the Sítio do Boqueirão, where a narrow rocky cliff forms a barrier to dune movement.

The textural contrast in the layers of P3 is very clear. The most abundant anthropogenic materials to a depth of $33 \mathrm{~cm}$ have a more clayey and silty texture than the surrounding soils, typically aeolian sand deposits. The textural characteristics of $\mathrm{P} 4$ indicate the palaeoenvironmental significance of the area. Apparently, there was a recent period in which the contribution of aeolian sand deposits was more significant than in previous periods (Table 1). The high $\mathrm{P}$ content in the surface layer (Table 2), similar to the subsurface stratum, shows that human activity was not responsible for the textural changes in $\mathrm{P} 4$.

The dark color and strong melanization, with low value and chroma in the studied profiles, is a common feature of layers under prolonged anthropogenic influence, due to the great accumulation of half-burnt organic matter related to the cultural habits of prehistoric peoples, as reported by Kern \& Kämpf (1989), Prous (1992), Lima (2001), Glaser et al. (2003), Kämpf et al. (2003), Myers et al. (2003), Woods (2003) and Corrêa (2007). In all horizons influenced by direct occupation of prehistoric peoples (letter $\mathrm{u}$ in the horizons), the value and chroma of the colors (Table 1) were lower. However, even layers considered sterile from the archaeological point of view, when underlying non-sterile layers, were strongly influenced by pigmenting organic matter. This can be explained by the probable eluviation of overlying organic colloids that are common in sandy coastal soils with high $\mathrm{Na}^{+}$ content. The colors (dry sample) of the anthropogenic horizons ranged from dark gray (10YR 4/1) to black (2.5Y 2/1) (Table 1).

\section{Chemical analysis}

The fertility of the studied midden soils was high (Table 2), and greater than in the soils of the surrounding areas (Camargo, 1979; Embrapa, 1979; Moniz et al., 1990; Ibraimo et al., 2004). This agrees with previous, indicating that under prolonged occupation, the soil color is darker and fertility levels higher than of adjacent soils (Kern \& Kämpf, 1989; Costa et al., 2002; Lima et al., 2002; Woods, 2003; Schaefer et al., 2004; Kämpf \& Kern, 2005; Corrêa, 2007).

Table 1. Physical and morphological characteristics: soil color, particle size distribution and textural class

\begin{tabular}{|c|c|c|c|c|c|c|c|}
\hline Horizon & Depth & Color & Coarse sand & Fina sand & Silt & Clay & Textural class \\
\hline & $\mathrm{cm}$ & dry & 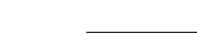 & dag $\mathrm{k}$ & 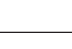 & $\square$ & \\
\hline \multicolumn{8}{|c|}{ Shellic chromic, eutric, medium texture Midden soil (P1 - Condomínio do Atalaia) } \\
\hline Apu & $0-40$ & 10YR $2 / 2$ & 44 & 23 & 17 & 16 & Sandy loam \\
\hline $\mathrm{ABu}$ & $40-55$ & $10 \mathrm{YR} 3 / 2$ & 43 & 23 & 18 & 16 & Sandy loam \\
\hline Biu 1 & $55-80$ & 10YR 3/2 & 44 & 23 & 16 & 17 & Sandy loam \\
\hline Biu 2 & $80-100$ & $10 \mathrm{YR} 3 / 2$ & 45 & 25 & 12 & 18 & Sandy loam \\
\hline $\mathrm{BCu}$ & $100-120$ & $10 \mathrm{YR} 3 / 3$ & 45 & 26 & 14 & 15 & Sandy loam \\
\hline $\mathrm{C} / \mathrm{R}$ & $120-130^{+}$ & 10YR 4/2 & 44 & 26 & 14 & 16 & Sandy loam \\
\hline \multicolumn{8}{|c|}{ Shellic melanic, eutric, medium texture Midden soil (P2 - Boqueirão) } \\
\hline $\mathrm{Au}$ & $0-35$ & $2,5 \mathrm{Y} 2,5 / 1$ & 34 & 25 & 22 & 19 & Sandy loam \\
\hline Biu & $35-60$ & $2,5 Y 3 / 1$ & 32 & 29 & 18 & 21 & Sandy clay loam \\
\hline $\mathrm{BCu}$ & $60-80$ & $2,5 \mathrm{Y} 3 / 2$ & 33 & 29 & 17 & 21 & Sandy clay loam \\
\hline $\mathrm{C} / \mathrm{R}$ & $80-100$ & $2,5 Y 3 / 1$ & 36 & 21 & 19 & 24 & Sandy clay loam \\
\hline \multicolumn{8}{|c|}{ Shellic chromic, arenic, Midden soil (P3 - Ilha do Cabo Frio) } \\
\hline $\mathrm{Au}$ & $0-10$ & 10YR 4/1 & 46 & 35 & 7 & 12 & Sandy loam \\
\hline $\mathrm{ACu}$ & $10-33$ & 10YR 5/1 & 47 & 33 & 7 & 13 & Sandy loam \\
\hline $\mathrm{C}$ & $33-80$ & 10YR 7/1 & 51 & 45 & 2 & 2 & Sandy \\
\hline $2 \mathrm{C}$ & $80-100^{+}$ & 10YR 7/1 & 58 & 36 & 4 & 2 & Sandy \\
\hline \multicolumn{8}{|c|}{ Shellic stratic, eutric, medium texture Midden soil (P4-Usiminas) } \\
\hline Apu & $0-10$ & 10YR 4/1 & 11 & 78 & 4 & 7 & Sandy \\
\hline $\mathrm{E}$ & $10-25$ & $10 \mathrm{YR} 5 / 1$ & 4 & 89 & 3 & 4 & Sandy \\
\hline $2 \mathrm{Au} 1$ & $25-40$ & 10YR 2/1 & 24 & 46 & 17 & 13 & Sandy loam \\
\hline $2 \mathrm{Au} 2$ & $40-60$ & 10YR 3/1 & 33 & 24 & 27 & 16 & Sandy loam \\
\hline $2 \mathrm{Au} 3$ & $60-80$ & 10YR 4/1 & 29 & 27 & 28 & 16 & Sandy loam \\
\hline $3 \mathrm{ACu} 1$ & $80-110$ & 10YR 3/1 & 25 & 34 & 29 & 12 & Sandy loam \\
\hline $3 \mathrm{ACu} 2$ & $110-145^{+}$ & 10YR 3/1 & 24 & 38 & 22 & 16 & Sandy loam \\
\hline
\end{tabular}


Table 2. Chemical properties of the studied soils

\begin{tabular}{|c|c|c|c|c|c|c|c|c|c|c|c|}
\hline \multirow{2}{*}{\multicolumn{2}{|c|}{ Horizon }} & \multicolumn{2}{|c|}{$\mathbf{p H}$} & \multirow{2}{*}{$\mathbf{P}$} & \multirow{2}{*}{$\mathrm{Na}^{+}$} & \multirow{2}{*}{$\mathrm{Ca}^{2+}$} & \multirow{2}{*}{$\mathrm{Mg}^{2+}$} & \multirow{2}{*}{$\mathbf{K}^{+}$} & \multirow{2}{*}{$\mathrm{Al}^{3+}$} & \multirow{2}{*}{$\mathbf{H}+\mathbf{A l}$} & \multirow{2}{*}{ OM } \\
\hline & & $\mathrm{H}_{2} \mathrm{O}$ & $\overline{\mathrm{KCl}}$ & & & & & & & & \\
\hline depth & $\mathrm{cm}$ & & & $\mathrm{mg} \mathrm{dm}$ & 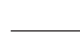 & 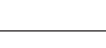 & $-\mathrm{cmo}$ & $m^{-3}$ & & & $\mathrm{~g} \mathrm{~kg}^{-1}$ \\
\hline \multicolumn{12}{|c|}{ Shellic chromic, eutric, medium texture Midden soil (P1-Condomínio do Atalaia) } \\
\hline Apu & $0-40$ & 7.06 & 5.87 & 5836.4 & 1.80 & 11.81 & 5.63 & 0.44 & 0.00 & 4.2 & 60.8 \\
\hline $\mathrm{ABu}$ & $40-60$ & 7.88 & 6.41 & 5254.2 & 1.32 & 8.91 & 5.67 & 0.28 & 0.00 & 1.9 & 41.6 \\
\hline Biu1 & $60-80$ & 8.16 & 6.60 & 7554.5 & 3.51 & 5.13 & 6.59 & 0.39 & 0.00 & 1.9 & 35.2 \\
\hline Biu2 & $80-100$ & 8.08 & 6.61 & 6769.1 & 3.33 & 5.15 & 5.67 & 0.47 & 0.00 & 2.3 & 35.2 \\
\hline $\mathrm{BCu}$ & $100-120$ & 8.19 & 6.68 & 6867.6 & 3.85 & 5.22 & 6.07 & 0.55 & 0.00 & 1.9 & 35.8 \\
\hline $\mathrm{C} / \mathrm{Ru}$ & $120-130^{+}$ & 8.21 & 6.84 & 5516.2 & 3.70 & 4.47 & 3.19 & 0.81 & 0.00 & 2.8 & 20.5 \\
\hline \multicolumn{12}{|c|}{ Shellic melanic, eutric, medium texture Midden soil (P2-Boqueirão) } \\
\hline $\mathrm{Au}$ & $0-35$ & 7.88 & 7.02 & 3950.3 & 1.99 & 14.20 & 3.11 & 0.38 & 0.00 & 0.0 & 96.0 \\
\hline Biu & $35-60$ & 8.62 & 7.30 & 3983.1 & 1.50 & 13.08 & 2.69 & 0.27 & 0.00 & 0.5 & 51.2 \\
\hline $\mathrm{BCu}$ & $60-80$ & 8.79 & 7.37 & 3484.4 & 1.69 & 8.46 & 2.66 & 0.12 & 0.00 & 0.5 & 32.0 \\
\hline $\mathrm{C} / \mathrm{R}$ & $80-100$ & 8.88 & 7.36 & 3336.7 & 1.41 & 7.67 & 0.89 & 0.11 & 0.00 & 0.5 & 19.2 \\
\hline \multicolumn{12}{|c|}{ Shellic chromic, arenic, Midden soil (P3-Ilha do Cabo Frio) } \\
\hline $\mathrm{Au}$ & $0-10$ & 8.69 & 7.85 & 415.3 & 0.60 & 5.38 & 0.65 & 0.04 & 0.00 & 0.5 & 21.8 \\
\hline $\mathrm{ACu}$ & $10-33$ & 8.59 & 8.24 & 318.4 & 0.34 & 3.65 & 0.53 & 0.02 & 0.00 & 0.5 & 12.8 \\
\hline $\mathrm{C}$ & $33-80$ & 8.80 & 8.76 & 315.9 & 0.40 & 1.71 & 0.18 & 0.02 & 0.00 & 0.5 & 26.0 \\
\hline $2 \mathrm{C}$ & $80-100^{+}$ & 8.72 & 8.77 & 213.0 & 0.23 & 2.01 & 0.23 & 0.02 & 0.00 & 0.3 & 38.0 \\
\hline \multicolumn{12}{|c|}{ Shellic stratic, eutric. medium texture Midden soil (P4-Usiminas) } \\
\hline $\mathrm{Apu}$ & $0-10$ & 8.19 & 6.59 & 3549.1 & 0.87 & 11.57 & 1.34 & 0.17 & 0.00 & 0.6 & 83.2 \\
\hline $\mathrm{E}$ & $10-25$ & 8.22 & 7.13 & 3688.5 & 0.91 & 12.98 & 1.63 & 0.09 & 0.00 & 0.3 & 89.6 \\
\hline $2 \mathrm{Au} 1$ & $25-40$ & 8.59 & 7.66 & 1967.9 & 1.19 & 11.87 & 2.66 & 0.19 & 0.00 & 0.2 & 71.6 \\
\hline $2 \mathrm{Au} 2$ & $40-60$ & 9.25 & 8.03 & 3267.2 & 8.44 & 6.60 & 5.39 & 0.82 & 0.00 & 0.0 & 55.0 \\
\hline $2 \mathrm{Au} 3$ & $60-80$ & 9.74 & 7.82 & 4185.1 & 7.59 & 4.60 & 4.20 & 0.75 & 0.00 & 0.0 & 35.8 \\
\hline $3 \mathrm{ACu} 1$ & $80-110$ & 8.65 & 8.13 & 185.2 & 1.18 & 3.82 & 0.51 & 0.08 & 0.00 & 0.8 & 12.8 \\
\hline $3 \mathrm{ACu} 2$ & $110-145^{+}$ & 8.36 & 8.14 & 238.2 & 1.55 & 4.38 & 0.96 & 0.12 & 0.00 & 0.5 & 20.5 \\
\hline
\end{tabular}

In the exchange complex, the levels of all cations were generally high, mainly of $\mathrm{Ca}^{2+}$ and $\mathrm{Mg}^{2+}$, of which the first was most abundant in almost all horizons. The reason is that the material with anthropogenic contributions is very rich in malacofauna shells of brackish water, consisting essentially of pure calcium carbonate (Corrêa, 2007). $\mathrm{Al}^{3+}$ is absent in the exchange complex, but levels are high in the lithological material of the area, in the form of aluminosilicates (Corrêa, 2007), indicating that at elevated water $\mathrm{pH}, \mathrm{Al}^{3+}$ activity in the medium decreased markedly, aside from the significant organic matter content that acts as a $\mathrm{Al}^{3+}$ complexant, restricting its activity (Parfitt, 1978). The soils are highly $\mathrm{Na}^{+}$-saturated, indicating strong influence of the salt spray brought by the constant winds to the coastal area, as pointed out by Ibraimo et al. (2004) in soils near the sites. Microchemical studies (Corrêa, 2007) showed many K-rich constituents in the sand fraction, e.g., feldspars and micas, and Na-rich components, such as sodic plagioclase, which also helped to increase the Na levels. These are little weathered soils, in which easily weathered primary minerals are preserved in the soil fractions.

The $\mathrm{P}$ contents extracted with Mehlich-1 were very high (Table 2), which is a characteristic feature of anthropogenic soils. In these soils, the available P level was higher than in any other Brazilian soil characterized before. In $\mathrm{P} 1$, where the levels are highest, the dating by Tenorio et al. (2005) was consistent with the results of this study, indicating that the longer pedogenesis facilitated a greater $\mathrm{P}$ release from anthropogenic materials (from fish remains, mainly) with consequent formation of secondary phosphates, which are preserved from dissolution due to the equilibrium conditions of the environment (high soil P availability), especially by the support of the dry regional climate. The lowest $\mathrm{P}$ levels in P3 can be explained by two factors: by the more sandy texture, where losses of $\mathrm{P}$ and other elements were more intense, and lower contribution and less accumulation of anthropogenic material than in other profiles. Even in strata that are sterile from the archaeological point of view, the $\mathrm{P}$ levels were high, indicating a vertical downward movement of $\mathrm{P}$ through leaching, as observed in $\mathrm{P} 4$.

It was assumed that the predominant $\mathrm{P}$ form in these soils was P-Ca (P bound to calcium) and that, although normally unstable, this $\mathrm{P}$ form can persist in the environment due to the high $\mathrm{pH}$ and high $\mathrm{P}$ and Ca contents in solution.

Of the micronutrients (Table 3), the values of $\mathrm{Cu}$ and $\mathrm{Zn}$ are noteworthy. Copper enrichment in anthropogenic environments is closely associated with 
Table 3. Values of some micronutrients extracted by Mehlich-1 in the fine earth of the studied soils

\begin{tabular}{|c|c|c|c|c|c|}
\hline \multicolumn{2}{|c|}{ Horizon } & Zn & $\mathbf{F e}$ & Mn & $\mathbf{C u}$ \\
\hline \multirow{2}{*}{\multicolumn{2}{|c|}{$\mathrm{cm}$}} & \multicolumn{4}{|c|}{$\mathrm{mg} \mathrm{dm}^{-3}$} \\
\hline & & \multicolumn{4}{|c|}{ Shellic chromic, eutric, medium texture Midden soil (P1 - Condomínio do Atalaia) } \\
\hline Apu & $0-40$ & 33.10 & 33.6 & 34.8 & 0.63 \\
\hline $\mathrm{ABu}$ & $40-60$ & 35.35 & 30.1 & 33.8 & 0.53 \\
\hline Biu1 & $60-80$ & 17.89 & 12.5 & 28.3 & 0.54 \\
\hline Biu2 & $80-100$ & 17.01 & 20.2 & 29.6 & 0.56 \\
\hline $\mathrm{BCu}$ & $100-120$ & 15.42 & 22.9 & 29.9 & 0.55 \\
\hline \multirow[t]{2}{*}{$\mathrm{C} / \mathrm{Ru}$} & $120-130^{+}$ & 21.57 & 114.1 & 36.0 & 0.55 \\
\hline & & \multicolumn{4}{|c|}{ Shellic melanic, eutric. medium texture Midden soil (P2 - Boqueirão) } \\
\hline $\mathrm{Au}$ & $0-35$ & 1.25 & 1.4 & 16.3 & 0.54 \\
\hline Biu & $35-60$ & 3.76 & 3.8 & 16.6 & 0.46 \\
\hline $\mathrm{BCu}$ & $60-80$ & 6.66 & 8.8 & 12.6 & 0.51 \\
\hline \multirow[t]{2}{*}{$\mathrm{C} / \mathrm{R}$} & $80-100$ & 6.82 & 18.9 & 14.1 & 0.50 \\
\hline & & \multicolumn{4}{|c|}{ Shellic chromic, arenic, Midden soil (P3 - Ilha do Cabo Frio) } \\
\hline $\mathrm{Au}$ & $0-10$ & 0.00 & 0.8 & 1.4 & 0.27 \\
\hline $\mathrm{ACu}$ & $10-33$ & 0.08 & 0.9 & 1.7 & 0.26 \\
\hline $\mathrm{C}$ & $33-80$ & 1.48 & 2.5 & 4.2 & 0.27 \\
\hline \multirow[t]{2}{*}{$2 \mathrm{C}$} & $80-100^{+}$ & 0.63 & 2.2 & 2.5 & 0.28 \\
\hline & & \multicolumn{4}{|c|}{ Shellic stratic, eutric. medium texture Midden soil (P4-Usiminas) } \\
\hline Apu & $0-10$ & 2.61 & 1.0 & 12.0 & 0.50 \\
\hline $\mathrm{E}$ & $10-25$ & 0.55 & 0.9 & 6.7 & 0.46 \\
\hline $2 \mathrm{Au} 1$ & $25-40$ & 0.10 & 0.9 & 5.7 & 0.35 \\
\hline $2 \mathrm{Au} 2$ & $40-60$ & 0.16 & 0.9 & 6.8 & 0.38 \\
\hline $2 \mathrm{Au} 3$ & $60-80$ & 1.57 & 4.2 & 11.1 & 0.48 \\
\hline $3 \mathrm{ACu} 1$ & $80-110$ & 0.00 & 2.1 & 2.5 & 0.33 \\
\hline $3 \mathrm{ACu} 2$ & $110-145^{+}$ & 0.00 & 2.5 & 75.8 & 0.34 \\
\hline
\end{tabular}

urine, but does not remain in the soil very long. According to Woods (2003), in about 2000 years most $\mathrm{Cu}$ is lost by leaching. Zinc is associated with feces and bones and much more stable in the soil than $\mathrm{Cu}$ (Woods, 2003), indicating layers of human occupation more clearly.

The highest Fe values (Table 3) in P1 and P2 were associated with the horizons $\mathrm{C} / \mathrm{R}$, where there must be redox variations related to Fe reduction, affecting Fe availability.

\section{Sulfuriphc acid attack}

The high $\mathrm{pH}$ values (Table 2) are favorable for Si activity and solubility, explaining its higher concentration in the deeper horizons (Table 4), indicating Si mobility in the profile. On the contrary, the solubility of $\mathrm{Al}_{2} \mathrm{O}_{3}$ and $\mathrm{Fe}_{2} \mathrm{O}_{3}$ was lower at higher $\mathrm{pH}$, allowing the persistence of higher values in comparison to $\mathrm{SiO}_{2}$ in the surface horizons.

The values of $\mathrm{Ki}$ and $\mathrm{Kr}$ (Table 4) showed the unfeasibility of considering these indexes, which are linked to weathering stages, in the study of shellmidden soils. The molecular relationships cannot portray the pedogenetic reality of these soils, nor indicate the nature of the clay mineralogy.

The high $\mathrm{P}_{2} \mathrm{O}_{5}$ contents (Table 4), especially in $\mathrm{P} 1$, $\mathrm{P} 2$ and $\mathrm{P} 4$, reinforce the predominant occurrence of phosphatic plasma in the clay fraction. The way of life of pre-Columbian people resulted in increased concentration of various elements in their settlement areas, especially of $\mathrm{P}$, present in urine, feces, and plant and animal tissues, such as bone (Woods, 2003). The high stability of $\mathrm{P}$ in the environment, especially in tropical climates (Novais \& Smyth, 1999), regardless of the soil conditions, make $\mathrm{P}$ a key element in studies of midden soils. Even strata or layers without abundance of stone, shell or bone fragments can contain extremely high $\mathrm{P}$ amounts, indicating its importance as marker of occupations in the past (Woods, 2003; Kämpf \& Kern, 2005; Goldberg \& Macphail, 2006).

\section{Total concentrations of elements}

The formation of shell-midden soils is quite different from the pedogenesis of the Dark Earths (DE) of the Amazon. In the midden soils of the Região dos Lagos, the separation of the anthropic from the non anthropic horizons in the field or through laboratory tests is particularly difficult. The reason are the interferences from activities of "sambaquieiros", the midden builders, in all horizons of the midden soils (P1, P2, P3 and P4), in contrast to other midden soils, e.g., the Amazon Dark Earths (Kern \& Kämpf, 1989; Lima et al., 2002; Woods, 2003; Schaefer et al., 2004; Corrêa, 2007 ), in which the pedogenic horizons with and 
without anthropogenic influence can be clearly distinguished. Therefore, the reading results of the $\mathrm{HF}$ attack are extremely important to assess the degree of anthropogenic influence on soils, although the contents of the elements contributed by human activity are underestimated due to the separation of materials by sieving $\leq 2 \mathrm{~mm}$ (fine earth). As a result, many bone fragments, shells, sea-urchin spikes and fishbones are excluded from quantification, despite the large element reserve they represent in the soils, especially of $\mathrm{P}, \mathrm{Ca}$ and $\mathrm{Mg}$.

The greatest reserves of $\mathrm{Fe}$, $\mathrm{Ti}$, and $\mathrm{Na}$, associated with naturally occurring materials in the horizons, are in the deeper horizons (Table 5), demonstrating a clear influence of local lithology (alkaline syenite or gneiss). This characteristic is valid for the profiles

Table 4. Contents of $\mathrm{Cu}, \mathrm{Mn}, \mathrm{Zn}, \mathrm{SiO}_{2}, \mathrm{Al}_{2} \mathrm{O}_{3}, \mathrm{Fe}_{2} \mathrm{O}_{3}, \mathrm{TiO}_{2}$ and $\mathrm{P}_{2} \mathrm{O}_{3}$ determined by sulfuric acid attack of ADFE

\begin{tabular}{|c|c|c|c|c|c|c|c|c|c|c|c|}
\hline \multicolumn{2}{|c|}{ Horizon } & \multirow{2}{*}{$\mathrm{Cu}$} & \multirow{2}{*}{ Mn } & \multirow{2}{*}{$\mathrm{Zn}$} & \multirow{2}{*}{$\mathrm{SiO}_{2}$} & \multirow{2}{*}{$\mathrm{Al}_{2} \mathrm{O}_{3}$} & \multirow{2}{*}{$\mathrm{Fe}_{2} \mathrm{O}_{3}$} & \multirow{2}{*}{$\mathrm{TiO}_{2}$} & \multirow{2}{*}{$\mathrm{P}_{2} \mathrm{O}_{5}$} & \multicolumn{2}{|c|}{ Molecular relations } \\
\hline & & & & & & & & & & Ki & $\mathbf{K r}$ \\
\hline \multirow[t]{2}{*}{ layer } & $\mathrm{cm}$ & 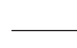 & $-\mathrm{mg} \mathrm{kg}$ & - & 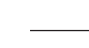 & 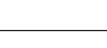 & $-\mathrm{g} \mathrm{kg}^{-1}$ & & - & & \\
\hline & \multicolumn{11}{|c|}{ Shellic chromic. eutric. medium texture Midden soil (P1 - Condomínio do Atalaia) } \\
\hline Apu & $0-40$ & 20.5 & 868 & 172 & 5 & 16 & 16 & 3.4 & 93.9 & 0.53 & 0.32 \\
\hline Biu1 & $60-80$ & 26.5 & 2383 & 173 & 6 & 24 & 28 & 3.2 & 120.9 & 0.43 & 0.24 \\
\hline \multirow[t]{2}{*}{$\mathrm{BCu}$} & $100-120$ & 21.3 & 748 & 95.3 & 25 & 24 & 29 & 2.9 & 81.8 & 1.77 & 1.00 \\
\hline & \multicolumn{11}{|c|}{ Shellic melanic. eutric. medium texture Midden soil (P2 - Boqueirão) } \\
\hline $\mathrm{Au} 0$ & $0-35$ & 18.8 & 663 & 122 & 1 & 25 & 16 & 2.5 & 84.5 & 0.07 & 0.05 \\
\hline \multirow[t]{2}{*}{ Biu 35} & $35-60$ & 12.8 & 350 & 86.3 & 41 & 36 & 24 & 4.1 & 51.4 & 1.94 & 1.36 \\
\hline & \multicolumn{11}{|c|}{ Shellic chromic. arenic. Midden soil (P3 - Ilha do Cabo Frio) } \\
\hline $\mathrm{Au}$ & $0-10$ & 3.5 & 142 & 20.0 & 4 & 1 & 8 & 3.4 & 11.3 & 6.80 & 1.11 \\
\hline \multirow[t]{2}{*}{$\mathrm{C}$} & $33-80$ & 1.5 & 117 & 15.5 & 1 & 1 & 7 & 3.2 & 2.3 & 1.70 & 0.31 \\
\hline & \multicolumn{11}{|c|}{ Shellic stratic. eutric. medium texture Midden soil (P4 -Usiminas) } \\
\hline Apu & $0-10$ & 5.5 & 221 & 54.0 & 6 & 7 & 9 & 2.1 & 21.5 & 1.46 & 0.80 \\
\hline $2 \mathrm{Au} 1$ & $25-40$ & 12.0 & 553 & 135 & 1 & 10 & 7 & 1.6 & 96.6 & 0.17 & 0.12 \\
\hline $3 \mathrm{ACu} 2$ & $110-145^{+}$ & 10.0 & 570 & 91.3 & 49 & 25 & 23 & 6.6 & 57.4 & 3.33 & 2.10 \\
\hline
\end{tabular}

Table 5. Total contents of oxides in the ADFE of the profiles P1, P2, P3 and P4

\begin{tabular}{|c|c|c|c|c|c|c|c|c|c|}
\hline \multicolumn{2}{|c|}{ Horizon } & \multirow[t]{2}{*}{$\mathrm{TiO}_{2}$} & \multirow[t]{2}{*}{$\mathrm{CaO}$} & \multirow[t]{2}{*}{$\mathrm{Fe}_{2} \mathrm{O}_{3}$} & \multirow[t]{2}{*}{$\mathrm{K}_{2} \mathrm{O}$} & \multirow[t]{2}{*}{ MgO } & \multirow[t]{2}{*}{$\mathrm{Na}_{2} \mathrm{O}$} & \multirow[t]{2}{*}{$\mathbf{P}_{2} \mathbf{O}_{5}$} & \multirow[t]{2}{*}{$\mathrm{MnO}$} \\
\hline layer & $\mathrm{cm}$ & & & & & & & & \\
\hline & & \multicolumn{8}{|c|}{ Shellic chromic. eutric. medium texture Midden soil (P1 - Condomínio Atalaia) } \\
\hline Apu & $0-40$ & 8.0 & 39.7 & 22.7 & 10.1 & 2.4 & 11.5 & 94.1 & 1.9 \\
\hline $\mathrm{Abu}$ & $40-60$ & 8.8 & 43.2 & 28.9 & 14.9 & 1.8 & 15.5 & 101.4 & 2.4 \\
\hline Biu1 & $60-80$ & 8.0 & 40.2 & 28.8 & 15.8 & 2.7 & 13.3 & 107.6 & 3.3 \\
\hline Biu2 & $80-100$ & 9.1 & 35.3 & 32.6 & 15.5 & 2.1 & 13.7 & 80.4 & 2.3 \\
\hline $\mathrm{BCu}$ & $100-120$ & 9.3 & 10.2 & 36.0 & 16.5 & 1.3 & 18.8 & 60.3 & 1.1 \\
\hline \multirow[t]{2}{*}{$\mathrm{C} / \mathrm{Ru}$} & $120-130^{+}$ & 10.4 & 5.0 & 36.7 & 23.4 & 0.5 & 25.1 & 44.8 & 0.8 \\
\hline & & \multicolumn{8}{|c|}{ Shellic melanic. eutric. medium texture Midden soil (P2 - Boqueirão) } \\
\hline $\mathrm{Au}$ & $0-35$ & 6.9 & 39.2 & 18.7 & 8.8 & 3.2 & 14.0 & 67.8 & 1.1 \\
\hline Biu & $35-60$ & 11.6 & 9.2 & 31.8 & 12.0 & 1.6 & 16.6 & 36.4 & 0.6 \\
\hline $\mathrm{BCu}$ & $60-80$ & 13.1 & 7.5 & 41.6 & 16.8 & 1.3 & 17.7 & 26.2 & 0.8 \\
\hline \multirow[t]{2}{*}{$\mathrm{C} / \mathrm{Ru}$} & $80-100$ & 10.3 & 4.2 & 47.6 & 17.8 & 0.5 & 19.1 & 14.8 & 0.3 \\
\hline & & \multicolumn{8}{|c|}{ Shellic chromic. arenic Midden soil (P3 - Ilha do Cabo Frio) } \\
\hline $\mathrm{Au}$ & $0-10$ & 10.9 & 50.1 & 12.8 & 6.6 & 2.7 & 8.4 & 17.2 & 0.3 \\
\hline Acu & $10-33$ & 8.7 & 42.5 & 10.4 & 6.4 & 2.3 & 7.7 & 11.2 & 0.2 \\
\hline \multirow[t]{2}{*}{$\mathrm{C}$} & $33-80$ & 8.2 & 31.2 & 10.3 & 5.1 & 1.8 & 6.3 & 0.0 & 0.2 \\
\hline & & \multicolumn{8}{|c|}{ Shellic stratic. eutric. medium texture Midden soil (P4-Usiminas) } \\
\hline Apu & $0-10$ & 3.3 & 18.1 & 8.3 & 11.3 & 1.6 & 8.0 & 18.0 & 0.1 \\
\hline $\mathrm{E}$ & $10-25$ & 2.2 & 6.5 & 6.2 & 12.3 & 0.9 & 8.4 & 9.5 & 0.1 \\
\hline $2 \mathrm{Au} 1$ & $25-40$ & 3.1 & 28.7 & 6.6 & 8.9 & 2.4 & 11.2 & 76.4 & 0.8 \\
\hline $2 \mathrm{Au} 2$ & $40-60$ & 3.4 & 19.4 & 7.2 & 5.2 & 2.7 & 9.1 & 115.7 & 0.5 \\
\hline $2 \mathrm{Au} 3$ & $60-80$ & 6.1 & 28.6 & 14.5 & 7.3 & 2.4 & 11.9 & 96.9 & 0.6 \\
\hline $3 \mathrm{ACu} 1$ & $80-110$ & 10.0 & 40.3 & 19.5 & 11.8 & 2.9 & 24.2 & 72.5 & 1.0 \\
\hline $3 \mathrm{ACu} 2$ & $110-145^{+}$ & 13.3 & 12.8 & 25.0 & 12.6 & 1.3 & 23.0 & 35.0 & 0.9 \\
\hline
\end{tabular}


P1, P2 and P4. The profile P3 differs from others by the location in the dune environment and therefore consist almost exclusively of quartz grains and are heavily influenced by salt-rich sea water. The Mn levels tended to be highest in the horizons under greatest human influence (Table 5).

A strong association of $\mathrm{Cu}$ with higher levels of human intervention (Table 6) was only observed in $\mathrm{P} 1$ and P2, where phosphatic clay plasma is more abundant (Corrêa, 2007). Zinc was the element with the strongest association to the horizons richest in human alterations, with similar efficiency as the $\mathrm{P}$ levels (Table 4) as indicator of past occupations. The levels of heavy elements such as $\mathrm{Pb}, \mathrm{Cr}$ and $\mathrm{Cd}$ were undetectable or very low (Table 6), indicating a low content of these elements in the materials added by the midden builders and in the rocks and sand components of the soil.

The saturation of adsorption sites of $\mathrm{P}$ and of other elements as well as the formation of ionic bonding allowed ion movement, even those of low mobility, along the profiles, hampering the separation of the pedogenic horizons with from those without anthropogenic influence (supposedly sterile). These features suggests the existence of other factors associated with the above: the constant movement of the terrain, excavations, burials and landfills in the middens (at the beginning of its use or reuse) caused a great blend of the layers; the construction of the shell mounds began on barren or incipient soil, with little influence on the current characteristics.

\section{CONCLUSIONS}

1. Pedological studies of archeological soils on shell middens represent key contributions to the reconstruction of past environments. Calcium, Mn, $\mathrm{Mg}$, and particularly $\mathrm{P}$ and $\mathrm{Zn}$ are indicators of anthropic soil horizons of coastal shell mounds (Sambaquis), similarly to the Amazon Dark Earths.

2. The soils of the Sambaquis of this region are extremely rich in both total and available $\mathrm{P}$, even compared to other archeological, midden soils, e.g., the Amazon Dark Earths. This is attributed to the more conservative, dry pedoclimate in the Região dos Lagos (RJ), where leaching is much reduced.

3. The contents of $\mathrm{Ca}, \mathrm{Mg}, \mathrm{Zn}, \mathrm{Mn}, \mathrm{Cu}, \mathrm{P}$, and organic $\mathrm{C}$ of midden soils are much higher than in regional soils without influence of ancient human settlements, demonstrating the long-standing high fertility, persisting for more than 4000 years at some sites.

4. Besides the obvious morphological and pedostratigraphic variations indicating anthropogenesis, the values of total $\mathrm{P}$ and $\mathrm{Zn}$ are the best chemical indicators of archeological/anthropogenic soil

Table 6. Total contents of trace elements in the ADFE of the profiles P1, P2, P3 and P4

\begin{tabular}{|c|c|c|c|c|c|c|}
\hline \multicolumn{2}{|c|}{ Horizon } & $\mathbf{P b}$ & Cd & $\mathrm{Cr}$ & $\mathrm{Cu}$ & $\mathrm{Zn}$ \\
\hline \multirow[t]{2}{*}{ layer } & \multirow[t]{2}{*}{$\mathrm{cm}$} & \multicolumn{5}{|c|}{$-\mathrm{mg} \mathrm{kg} \mathrm{kg}^{-1}$} \\
\hline & & \multicolumn{5}{|c|}{ Shellic chromic, eutric, medium texture Midden soil (P1 - Condomínio do Atalaia) } \\
\hline $\mathrm{Apu}$ & $0-40$ & 0.0 & 0.0 & 0.0 & 14.8 & 266.2 \\
\hline $\mathrm{ABu}$ & $40-60$ & 0.0 & 0.0 & 0.0 & 30.3 & 310.6 \\
\hline Biu1 & $60-80$ & 0.0 & 0.0 & 0.0 & 26.6 & 242.4 \\
\hline Biu2 & $80-100$ & 0.0 & 0.0 & 0.0 & 20.0 & 166.5 \\
\hline $\mathrm{BCu}$ & $100-120$ & 0.0 & 0.0 & 0.0 & 13.5 & 99.5 \\
\hline \multirow[t]{2}{*}{$\mathrm{C} / \mathrm{Ru}$} & $120-130^{+}$ & 0.0 & 0.0 & 0.0 & 2.9 & 61.2 \\
\hline & & \multicolumn{5}{|c|}{ Shellic melanic, eutric. medium texture Midden soil (P2 - Boqueirão) } \\
\hline $\mathrm{Au}$ & $0-35$ & 0.0 & 0.0 & 0.0 & 6.3 & 143.7 \\
\hline Biu & $35-60$ & 0.0 & 0.0 & 0.0 & 3.5 & 101.9 \\
\hline $\mathrm{BCu}$ & $60-80$ & 0.0 & 0.0 & 0.5 & 1.0 & 83.0 \\
\hline \multirow[t]{2}{*}{$\mathrm{C} / \mathrm{Ru}$} & $80-100$ & 0.0 & 0.0 & 0.0 & 0.0 & 38.1 \\
\hline & & \multicolumn{5}{|c|}{ Shellic chromic, arenic, Midden soil (P3 - Ilha do Cabo Frio) } \\
\hline A1u & $0-10$ & 0.0 & 0.0 & 0.0 & 0.0 & 0.0 \\
\hline Acu & $10-33$ & 0.0 & 0.0 & 0.0 & 0.0 & 0.0 \\
\hline \multirow[t]{2}{*}{$\mathrm{C}$} & $33-80$ & 0.0 & 0.0 & 0.0 & 0.0 & 0.0 \\
\hline & & \multicolumn{5}{|c|}{ Shellic stratic, eutric. medium texture Midden soil P4-Usiminas) } \\
\hline Apu & $0-10$ & 0.0 & 0.0 & 0.0 & 0.0 & 11.8 \\
\hline $\mathrm{E}$ & $10-25$ & 0.0 & 0.0 & 0.0 & 0.0 & 0.0 \\
\hline $2 \mathrm{Au} 1$ & $25-40$ & 0.0 & 0.0 & 0.0 & 0.0 & 157.7 \\
\hline $2 \mathrm{Au} 2$ & $40-60$ & 0.0 & 0.0 & 0.0 & 0.0 & 169.3 \\
\hline $2 \mathrm{Au} 3$ & $60-80$ & 0.0 & 0.0 & 0.0 & 0.0 & 153.7 \\
\hline $3 \mathrm{ACu} 1$ & $80-110$ & 0.0 & 0.0 & 0.0 & 0.0 & 129.0 \\
\hline $3 \mathrm{ACu} 2$ & $110-145^{+}$ & 0.0 & 0.0 & 0.0 & 0.0 & 80.7 \\
\hline
\end{tabular}


horizons derived from shell middens. After deposition of P-rich debris, $\mathrm{P}$ reaction and leaching can mask the evidence of in situ man-made strata, but the mineralogical and chemical studies of phosphate forms can help clarify the apparent complexity. Phosphaterich lower strata without direct anthropic inputs indicate $\mathrm{P}$ leaching and precipitation in secondary $\mathrm{P}$ forms.

5. Based on the morphology and pedostratigraphy, the degree of pedobioturbation of the studied horizons is comparatively lower than in other anthropogenic soils studied in Brazil, such as the Amazon Dark Earths. This was attributed to the local drier climate and lower biological activity.

6 . The contribution of aeolian sand deposits significantly increased the sand fraction in the analyzed soils, which all belonged to the texture classes sand, sandy loam and sandy clay loam. The aeolian sand accumulation occurred simultaneously with the midden formation.

\section{ACKNOWLEDGEMENTS}

We thank the Brazilian Navy (Instituto de Estudos do Mar Almirante Paulo Moreira (Arraial do Cabo ) for logistic support; and Dr. Maria C. Tenório for useful comments during field work.

\section{LITERATURE CITED}

ABREU, S.F. Sambaquis de Imbituba and Laguna. R. Soc. Geogr., 28:8-50, 1928.

BARBOSA, D.B. \& DUDA, J. Sistematização e cartografia dos testemunhos pré-históricos dos pescadores, coletores e caçadores do estado de Santa Catarina: Um estudo de caso. B. Museu Paraense Emilio Goeldi, Sér. Ci. Terra, 8:80-88, 1996.

BIGARELLA, J.J. Os Sambaquis na evolução da paisagem litorânea sul-brasileira. Arq. Biol. Tecnol., 9:199-221, 1954.

BRASIL. Ministério de Minas e Energia. Projeto Radambrasil, Folhas SF 23/24. Rio de Janeiro/Vitória, geologia, geomorfologia, pedologia, vegetação e uso potencial da terra. Rio de Janeiro, 1983. 775p. (Levantamento de Recursos Naturais, 32)

CAMARGO, M.N. Guia de excursão de estudos de solos no estado do Rio de Janeiro. In: REUNIÃO DE CLASSIFICAÇÃO, CORRELAÇÃO E INTERPRETAÇÃO DE APTIDÃO AGRÍCOLA DE SOLOS, 1., Rio de Janeiro, 1979. Anais... Campinas, Sociedade Brasileira de Ciência do Solo, 1979. p.77-246.

CORRÊA, G.R. Caracterização pedológica de arqueoantropossolos no Brasil: Sambaquis da Região dos Lagos (RJ) e terras pretas do índio na região do baixo rio Negro/ Solimões. Viçosa, MG, Universidade Federal de Viçosa, 2007. (Tese de Mestrado)
COSTA, M.L.; KERN D.C.; BEHLING,H. \& BORGES, M.S. Geologia. In: LISBOA, P.L.B. (org.). Caxiuanã, populações tradicionais, meio físico \& diversidade biológica. Belém, 2002. 734p.

DUARTE, P. O Sambaqui visto através de alguns Sambaquis. Pré-história brasileira. São Paulo, IPH-USP, 1968. p.45142.

EMPRESA BRASILEIRA DE PESQUISA AGROPECUÁRIA EMPRAPA. Serviço Nacional de Levantamento e Conservação de Solos. In: REUNIÃO DE CLASSIFICAÇÃO, CORRELAÇÃO E INTERPRETAÇÃO DA APTIDÃO AGRÍCOLA DE SOLOS, 1., Rio de Janeiro, 1979. Anais... Rio de Janeiro, 1979. 276p.

EMPRESA BRASILEIRA DE PESQUISA AGROPECUÁRIA EMPRAPA. Centro Nacional de Pesquisa de Solo. Manual de métodos de análises do solo. 2.ed. Rio de Janeiro, 1997. $212 \mathrm{p}$.

FIGUTI, L. Economia/alimentação na pré-história do litoral de São Paulo. In: TENÓRIO, M.C. (org.). Pré-história da terra Brasilis. Rio de Janeiro, Universidade Federal de Juiz de Fora, 1999

GASPAR, M.D. Os ocupantes pré-históricos do litoral brasileiro. In: TENÓRIO, M.C.,org. Pré-história da terra Brasilis. Rio de Janeiro, Universidade Federal de Juiz de Fora, 1999.

GLASER, B.; GUGGENBERGER, G.; ZECH, W. \& RUIVO, M.L. Soil organic matter stability in Amazonian Dark earths. In: LEHMANN, J.; KERN, D.C.; GLASER, B. \& WOODS, W.I., eds. Amazonia Dark earths: Origin, properties and management. Dordrecht, Kluwer Academic Publishers, 2003. p.141-158.

GOLDBERG, P. \& MACPHAIL, R.I. Practical and theoretical geoarchaeology. Oxford, Blackwell Publishing, 2006. 454p.

IBRAIMO, M.M.; SCHAEFER, C.E.G.R.; KER, J.C.; LANI, J.L.; ROLIM-NETO, F.C.; ALBUQUERQUE, M.A. \& MIRANDA, V.J. Gênese e micromorfologia de solos sob vegetação xeromórfica (caatinga) na Região dos Lagos (RJ). R. Bras. Ci. Solo, 28:695-712, 2004.

KÄMPF, N.; WOODS, W.I.; SOMBROEK, W.; KERN, D.C. \& CUNHA, T.J.F. Classification of Amazonian Dark Earths and other ancient antropic soils. In: LEHMANN, J.; KERN, D.C.; GLASER, B. \& WOODS, W.I., eds. Amazonia Dark earths. Origin, properties and management. Dordrecht, Kluwer Academic Publishers, 2003. p.77-102.

KÄMPF, N. \& KERN, D.C. O solo como registro da ocupação humana pré-histórica na Amazônia. In: VIDALTORRADO, P.; ALLEONI, L.R.F.; COOPER, M.; SILVA, A.P. \& CARDOSO, E.J., eds. Tópicos em ciência do solo. Viçosa, MG, Sociedade Brasileira de Ciência do Solo, 2005. v.4. p.277-320.

KERN, D.C. \& KÄMPF, N. Antigos assentamentos indígenas na formação de solos com Terra Preta Arqueológica na região de Oriximiná, Pará. R. Bras. Ci. Solo, 13:219-225, 1989 .

KRÖNE, R. Informações etnográficas do Vale do Rio da Ribeira de Iguape. São Paulo, Comissão Geográfica e Geológica de São Paulo, 1914. 33p. 
KUO, S. Phosphorus. In: SPARKS, D.L.; PAGE, A.L.;HELMKE, P.A.; LOEPPERT, R.H. SOLTANPOUR, P.N.; TABATABAI, M.A.; JOHNSTON, C.T. \& SUMMER, M.E. eds. Methods of soil analysis. Chemical methods.Madison, Soil Science Society of America/American Society of Agronomy, 1996. Part 3. p.869-919.

LEONARDOS, O.H. Concheiros naturais e sambaquis. Departamento Nacional da Produção Mineral; Serviço de Fomento da Produção Mineral. Papéis Avulsos, 37:1-109, 1938.

LIMA, H.N. Gênese, química, mineralogia e micromorfologia de solos da Amazônia Ocidental. Viçosa, MG,Universidade Federal de Viçosa, 2001. 176p. (Tese de Doutorado)

LIMA, H.N.; SCHAEFER, C.E.G.R.; MELLO, J.W.V.; GILKES, R.J. \& KER, J.C. Pedogenesis and pre-Colombian land use of "Terra Preta Anthrosol" ("Indian black earth") of Western Amazonia. Geoderma, 100:1-17, 2002.

LIMA, T.A. Em busca dos frutos do mar: Os pescadorescoletores do litoral centro-sul do Brasil. R. USP, 44:270327, 1999-2000.

MONIZ, A.C.; GRANDE, M.A. \& OLIVEIRA, V. Solos do trecho Cabo Frio-Xerém (RJ): Influência de regimes pluviais e de material de origem na pedogênese. R. Bras. Ci. Solo, 14:205-214, 1990.

MYERS, T.P.; DENEVAN, W.M.; WINKLERPRINS, A. \& PORRO, A. Historical perspectives on Amazonian Dark Earths. In: LEHMANN, J.; KERN, D.C.; GLASER, B. \& WOODS, W.I., eds. Amazonia Dark earths. Origin, properties and management. Dordrecht, Kluwer Academic Publishers, 2003. p.15-24.

NOVAIS, R.F. \& SMYTH, T.J. Fósforo em solo e planta em condições tropicais. Viçosa, MG, Universidade Federal de Viçosa, 1999. 399p.

PARFITT, R.L. Parfitt, Anion adsorption by soils and soil materials. Adv. Agron., 30:1-50, 1978.

PENNA, D.S.F. Breve notícia sobre os sambaquis do Pará. Arq. Museu Nacional, 2:47-76, 1877.

PENNA, D.S.F. Breve notícia sobre os sambaquis do Pará. In: CONSELHO ESTADUAL DE CULTURA BELÉM-PARÁ. Obras completas de Domingos Soares Ferreira Penna. Belém, 1973.
PROUS, A. Arqueologia brasileira. Brasília, Universidade de Brasília, 1992.

ROOSEVELT, A.C. Determinismo ecológico na interpretação do desenvolvimento social indígena da Amazônia. In: NEVES, W., ed. Origem, adaptações e diversidade biológica do homem nativo da Amazônia. 1991. p.103-159. (Coleção Emílie Snethlage, Museu Paraense Emílio Goeldi)

RUIZ, H.A. Dispersão física do solo para análise granulométrica por agitação lenta. In: CONGRESSO BRASILEIRO DE CIÊNCIA DO SOLO, 30., Recife, 2005. Anais... Recife, Sociedade Brasileira de Ciência do Solo, 2005a. CD ROM.

RUIZ, H.A. Incremento da exatidão da análise granulométrica do solo por meio da coleta da suspensão (silte + argila). R. Bras. Ci. Solo, 29:297-300, 2005b.

SANTOS, R.D.; LEMOS, R.C.; SANTOS, H.G.; KER, J.C. \& ANJOS, L.H.C. Manual de descrição e coleta de solo no campo. 5.ed. Viçosa, MG, Sociedade Brasileira de Ciência do Solo, 2005. 92p.

SCHAEFER, C.E.G.R.; LIMA, H.N.; GILKES, R.J. \& MELLO, J.W.V. Micromorphology and electron microprobe analysis of phosphorus and potassium forms of an Indian Black Earth (IBE) Anthrosol from Western Amazonia. Austr. J. Soil Res., 42:401-409, 2004.

TENÓRIO, M.C.; AFONSO, M.C.; SAVI, D.C.; PINTO, D.C.; GONZALEZ, M.; NAMI, S.; ÂNGULO, R. \& REIMER, P.J. O sítio ou os sítios de Ilha do Cabo Frio: Primeiros resultados. In: CONGRESSO DA SOCIEDADE DE ARQUEOLOGIA BRASILEIRA, 8., Campo Grande, 2005. Anais... Campo Grande, Oeste, 2005. CD ROM.

USDA. Soil Survey Laboratory. Methods manual. Lincoln, Nebraska, National Soil Survey Center, 1996.

WOODS, W.I. Development of anthrosol research. In: LEHMANN, J.; KERN, D.C.; GLASER, B. \& WOODS, W.I., eds. Amazonia Dark Earths. Origin, properties and management. Dordrecht, Kluwer Academic, 2003. p.2949. 
